\title{
Model Literasi Media di Lingkungan Rumah Panti Asuhan
}

\author{
Sigit Tripambudi dan Dewi Novianti \\ Program Studi Ilmu Komunikasi UPN Veteran Yogyakarta \\ Email: dewinovianti_upn@yahoo.co.id
}

\begin{abstract}
Abstact
The development of television and internet has brought new anxiety that is problem of media's content, which is convinced presenting uneducated broadcast programs. The cheaper and wider interactive media also represent anxiety itself. Pornography site, online game, social media have pushed to consume much time and given an attention students so that they consumed time and concern in studying. The healthy internet concept is difficult to apply due to the very personal character. Therefore, the understanding of literacy media is needed as self-control. The research investigate model of media literacy at the orphanage and poor reformatory house of Ibnu Fatah Berbah Sleman Yogyakarta. Through qualitative study, the research conclude that the used of mass media and internet media in the house-yard of the orphanage and poor reformatory house of Ibnu Fatah Berbah Sleman Yogyakarta is observed, however the orphanage children always look for opportunity behind back. They are more enthusiastic with internet media rather than mass media. They keep to access negative sites even though they realize the matter is negative and destructive. It is required model of literacy media with schema: first, create open communication system between reformatory caretaker and the orphanage children. Second, engraft strong Islamic value system either in cognitive, affective and cognacs as self-control. Third, introduce positive and negative keywords, fourth, provide tool of used access media in directed and staged.
\end{abstract}

Keywords: literacy media, mass media, internet media

\begin{abstract}
Abstrak
Perkembangan televisi dan internet telah membawa kecemasan baru, yaitu masalah isi (content) media, yang diyakini banyak menghadirkan program siaran yang tidak mendidik. Media interaktif yang semakin murah dan tersebar juga menghadirkan kecemasan tersendiri. Situs pornografi, permainan online, media sosial telah menyita waktu dan perhatian pelajar sehingga menyita waktu dan perhatian dalam belajar. Konsep berinternet yang sehat sulit untuk diterapkan karena sifatnya yang sangat personal. Oleh karena itu pemahaman literacy media sangat diperlukan sebagai self control. Penelitian ini mencari model literacy media di Panti Asuhan Yatim Piati dan Fakir Miskin Ibnu Fatah Berbah Sleman Yogyakarta. Melalui studi kualitatif penelitian ini menyimpulkan bahwa penggunaan media massa dan media internet di lingkungan Panti Asuhan Yatim Piatu dan Fakir Miskin Ibnu Fatah Berbah Sleman sangat dibatasi dan dipantau, namun anak-anak panti selalu mencari kesempatan. Mereka lebih antusias dengan media internet dari pada media ,massa. Mereka tetap mengakses situsnegatif walaupun mereka juga menyadari hal tersebut merusak. Diperlukan model media literacy dengan skema : Pertama, membuat system komunikasi yang terbuka antara pengasuh panti dan anak-
\end{abstract}


anak panti. Kedua, menanamkan sistem nilai ajaran Islam yang kuat baik secara kognisi, afeksi dan kognasi sebagai self control. Ketiga, memperkenalkan kata-kata kunci positif dan negatif, Keempat, menyediakan sarana akses media yang digunakan secara terbimbing dan terjadwal.

Kata kunci : media literacy, media massa, media internet

\section{Pendahuluan}

Dewasa ini media telah tumbuh dan berkembang dengan pesat. Selain media massa, media interaktif juga mengalami lompatan pengguna yang mencengangkan. Pada tahun 2012 tercatat ada sekitar 60 juta pengguna internet di Indonesia, namun pada tahun 2014 telah naik munjadi dua kali lipat, yaitu kurang lebih 120 juta. Jumlah ini akan terus bertambah dengan pesat di waktu yang akan datang.

Perkembangan media tersebut telah membawa kecemasan baru, yaitu masalah isi (content). Media massa, khususnya televisi, diyakina banyak menghadirkan program siaran yang tidak mendidik. Mereka lebih mengedepankan program-program hiburan yang kurang memperhatikan etika dan norma masyarakat. Mereka tidak peduli dampak negatif program siaran yang dikedepankan tersebut. Misalnya adalah eksploitasi terhadap perempuan, anak, kemiskinan, humor yang rendah, gaya hidup bebas dan sebagainya.

Media interaktif yang semakin murah dan tersebar juga menghadirkan kecemasan tersendiri. Situs pornografi, permainan online, media sosial telah menyita waktu dan perhatian pelajar sehingga menyita waktu dan perhatian dalam belajar. Konsep berinternet yang sehat sulit untuk diterapkan karena sifatnya yang sangat personal. Pemantauan dan pendampingan oleh orang tua maupun guru di sekolah juga sulit dilakukan karena sifatnya yang self control atau swakrama. Sebuah riset tentang penggunaan internet di kalangan pelajar SMU di Yogyakarta cukup mencengangkan jarena seratus persen responden pernah mengakses situs porno.

Salah satu cara untuk mengontrol penggunaan media yang sekaligus untuk meminimalkan dampak negatifnya adalah dengan menanamkan self kontrol yang kuat. Hal ini dapat dilakukan dengan menanamkan sistem nilai yang kuat. Oleh karena itu perlu dirumuskan model penggunaan media dalam bentuk media literacy yang dipadu dengan penanaman nilai moral keagamaan yang bersifat religius.

Panti asuhan yatim piatu dan fakir miskin Ibnu Fatah adalah rumah penampungan pelajar yang terletak di Berbah Sleman Yogyakarta. Sebagian besar penghuni panti ini adalah pelajar tingkat SMP dan SMU/SMK. Mereka berasal dari keluarga tidak mampu. Aktivitas mereka belajar di sekolah-sekolah yang ada di sekitar panti. Sedangkan ketika di luar waktu sekolah ada sesi waktu yang digunakan untuk pembelajaran agama Islam.

Target Panti asuhan yatim piatu dan fakir miskin Ibnu Fatah adalah menciptakan generasi yang terpelajar dan berakhlak mulia. Mereka mengikuti perkembangan ilmu pengetahuan namun tetap dalam kerangka kaidah-kaidah keagamaan. Oleh karena itu mereka tetap harus berinteraksi dengan media sebagai sumber informasi namun dengan self kontrol sebagai filternya. Inilah pentingnya media literacy. Penelitian ini akan beruapaya menemukan model media literacy di panti asuhan yatim piatu dan fakir miskin Ibnu Fatah Berbah Sleman Yogyakarta dengan melihat konteks fisik, mental dan social di lingkungan panti tersebut.

Pemahaman media literacy atau melek media secara sederhana adalah bagaimana khalayak mampu memilih atau menyaring isi pesan yang disampaikan oleh media. Khalayak mampu membedakan mana yang dianggap penting atau baik dan mana yang dianggap buruk. Pada dataran ini khalayak sudah semakin cerdas, 
aktif dan kritis. Bahkan khalayak tidak begitu saja mempercayai pesan yang disampaikan oleh media. Untuk itulah dibutuhkan adanya media edukasi dalam konteks media literacy. Wirodono dalam Rejeki (2010:67) mengemukakan tiga kategori khalayak yang rentan terhadap pengaruh buruk media, yakni anak-anak, remaja, dan kaum ibu.

Pada anak-anak, pengaruh itu terutama terletak pada perkembangan otak, emosi, sosial, dan kemapuan kognitif. Intensitas akan mempengaruhi pada persepsi dengan apa yang mereka tonton. Kekhawatiran tersebut misalnya pengaruh tayangan kekerasan pada anak-anak yang sering meniru bentuk tontonan.selain itu tayangan berbau seks dan mistis menjadi kekhawatiran para ibu-ibu.

Pada remaja, tayangan sinetron dengan tema remaja cenderung mengeksploitasi kehidupan remaja dari satu sisi. Keadaan ini menyebabkan remaja tidak bisa mempelajari realitas yang sesngguhnya. Bagi ibu-ibu pengaruh buruk televisi lebih pada membangun perilaku konsumtif. Mereka merupakan sasarn potensial iklan. Komoditas ini dikemas dalam bentuk tayangan sinetron, infotainment, tayangan kuliner dan sebagainya (Wirodono dalam Rejeki, 2010:69).

Diskusi seputar pendidikan dan media massa mau tak mau melarikan kita pada diskusi besar yang tak pernah berakhir seputar efek media massa: positif atau negatif. Bertitiktolak dari pandangan ini, maka relasi antara media massa dan pendidikan dipandang sebagai sesuatu yang niscaya bersifat positif - keduanya merupakan subsistem dalam sistem masyarakat, unit kecil dari pranata kultural dengan fungsinya masingmasing. Media massa sebagai sarana komunikasi memiliki fungsi sebagai perangkat transmisi, atau sebagai pemelihara social bondingsikatan-ikatan sosial.

Sementara, pranata pendidikan memiliki fungsi memelihara unit sosial melalui sosialisasi nilai-nilai kultural-fungsi edukatif pendidikan lewat social maintenance. Pendidikan dan media massa bisa berada dalam satu pranata kultural.
Tapi bisa juga berada dalam subsistem yang berbeda. Namun, apakah dalam subsistem yang sama ataupun terpisah, relasi antara keduanya, dalam paradigma fungsionalisme struktural, senantiasa dimaknai positif.

Teori kekeran Televisi, memandang bahwa kekerasan adalah perkembangan yang bertahap dan sekumpulan teori yang merangkum temuan dan menawarkan wawasan yang berguna bagi peran media dalam kehidupan anaanak. Diambil bersama, mereka menawarkan dukungan yang kuat hubungan antara menonton televisi dan agresi. Aletha Huston dan koleganya berpendapat ; " akumulasi penelitian secara jelas menggambarkan sebuah hubungan antara melihat kekerasan dan perilaku agresif yaitu penonton berat berperilaku lebih agresif daripada penonton ringan.

Studi eksperimen maupun Longitudinal mendukung hipotesis bahwa melihat kekerasan diasosiaiskan dengan agresi. Pengalaman lapangan (alamiah) dengan anak-anak sebelum sekolah dan remaja menemukan agresi yang memuncak diantara pemirsa yang dimita melihat kekerasan di televisi atau film dalam kondisi tertentu (Baran \& Davis, 2010, 225)

Media massa, dengan menyeleksi eventevent tertentu, atau dengan membahasakan dan melabeli fakta-fakta tertentu, menciptakan kesadaran semu di tengah masyarakat seputar realitas sosial yang mereka hadapi. Media massa memiliki kuasa seperti ini, karena politik pengemasan berita dan isi media lain pada umumnya tidaklah bersifat objektif sama sekali, melainkan sangatlah subjektif.

Dalam Teori Pembelajaran Sosial, manusia belajar dari observasi. Seorang penonton televisi yang masih muda cenderung mengimitasi dari apa yang mereka lihat. Imitasi merupakan duplikasi langsung perilaku yang diamati. Pengaruh media yang begitu mentah dan bersifat negatif hanya menerpa bagi mereka yang "rentan" akan agresi (Baran \& Davis, 2010, 227).

Di sisi lain, kehadiran media massa yang belum mampu secara dewasa menyikapi kebebasannya menyebabkan ekses-ekses 
negatifnya-seperti pornografi, pelanggaran batas privasi, ekspos kekerasan dan mistik supranatural yang berlebihan-lebih banyak 'dirayakan' publik ketimbang memberi pembelajaran bagi publik bagaimana menjadi warganegara yang bertanggungjawab dalam sistem negara yang demokratis.

Media massa dalam era keterbukaan dan kebebasan pers sekarang ini nyatanya tetap menjadi alat kepentingan kelompok berkuasa. Karena itu, dalam situasi era Reformasi sekarang ini, tetap saja media massa tidak bebas sepenuhnya mewujudkan dirinya - media massa bagaimanapun merupakan ajang kontestasi berbagai kepentingan. Ketika media massa tidak lagi dikuasai negara, maka jatuhlah media massa pada tangan kekuatan ekonomi-yang mewujud dalam bentuk kapitalisme liberal. Gejala inilah yang disinyalir terjadi dalam konstelasi media massa di Indonesia belakangan ini, yaitu jatuhnya media massa dalam kekuatan-kekuatan ekonomi kapitalis neoliberal yang mementingkan profit semata (Hidayat, 2000). Inilah yang membuat media massa saat ini seolah menjadi public enemy—musuh masyarakat.

Metode

Penelitian

Penelitian ini adalah penelitian kualitatif yang sering diistilahkan dengan penelitian naturalistik dalam bidang Sosiologi, penelitian etnografi dalambidangAntropologi dan penelitian studi kasus dalam bidang Psikologi (Sutopo, 2001 : 5-6). Neuman (2000 : 65) menyebutkan adanya tiga perspektif dalam Ilmu Sosial yang akan membedakan dalam teknik penelitian, yaitu : Positivist, interpretive dan critical. Pendekatan kuantitatif berada di bawah perspektif positivist, sedangkan pendekatan kualitatif berada di bawah perspektif interpretive/constructivis dan critical (Neuman, $2000: 65$ )

Penelitian ini masuk dalam kategori constructivis social research. Pemikiran ini dapat ditelusuri sejak Sosiolog Jerman Max Weber (1864-1920) dan Filosof Jerman Wilhem Dilthey (1833-1911). Dilthey membedakan dua jenis ilmu secara mendasar, yaitu :
Naturwissenchachaft (berdasarkan pemahaman abstrak) dan Geisteswissenchaff (berdasarkan pemahaman empathetic). Sedangkan Weber berpendapat bahwa llmu sosial membutuhkan studi makna tindakan sosial.

Informan dalam peneelitian ini adalah anak-anak dan pengasuh panti asuhan yatim piatu dan fakir miskin Ibnu Fatah Berbah Slemanm serta pengamat media. Teknik pengumpulan datanya melalui wawancara, observasi dan analisa dokumen. Uji validitasnya menggunakan triangulasi sumber dan triangulasi metode. Teknik analisa datanya menggunakan teknik analisa interaktif.

Hasil Penelitian dan Pembahasan Panti asuhan Ibnu Fatah berdiri pada hari Senin tanggal 24 maret 2008 dengan akte Notaris Ahmad Dien Prawirakarsa, SH. bertempat di dusun Karang Tengah, desa Margosari, Kecamatan Pengasih Kabupaten Kulon progo. Didirikan oleh Arwan Zuwardi, Sri Tentrem, Yanudi, dan Pauyan Alim. Tujuan utamanya tidak lain adalah untuk membantu masyarakat yang kurang mampu dan membutuhkan.

Setelah membangun lokal Panti mulailah diisi oleh beberapa anak-anak yatim piatu dan dhua'fa. Mereka mendapatkan akomodasi segala keperluan berupa fasilitas tinggal, keperluan sehari-hari dan sekolah. Pada perkembangannya panti tersebut membuka cabang di Berbah Sleman pada tahun 2000an.

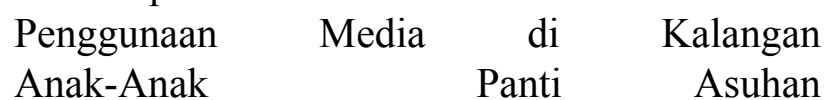

Panti Asuhan Yatim Piatu dan Fakir Miskin Ibnu Fatah Berbah Sleman berlandaskan ajaran Agama Islam. Selain mengikuti pendidikan formal, anak-anak panti diwajibkan menekuni atau memperdalam ajaran Islam. Mereka menghabiskan waktu luang mereka untuk mendalami ajaran Islam. Harapannya adalah setiap anak dapat cerdas secara edukasional dan spiritual.

Untuk mendukung terwujudnya harapan tersebut, pengelola peraturan. Salah satunya adalah yang berkaitan dengan penggunaan 
media, baik media massa maupun media interaktif. Misalnya mereka hanya diijinkan menonton siaran TV hanya pada jam 20.00-22.00 setiap Sabtu malam. Pengasuh panti membatasi jam menonton TV ka rena meyakini bahwa siaran TV akan membawa banyak dampak yang negative. Waktu bias digunakan untuk kegiatan yang positif dari pada untuk sekedar menonton siaran TV.

Program siaran televise yang mereka tonton cukup bervariasi, bergantung pada kegemaran mereka.' Misalnya adalah berita, sepak bola, film, music, reality show dan sebagainya. Salah seorang anak penghuni panti yang bernam Pramono, menjelaskan :" Kebanyakan siaran mengenai sepak bola dan permainannya, kalau film, music, reality show jarang, dikarenakan tidak terlalu suka selain itu juga membosankan". Namun demikian ada juga anak panti yang tidak memanfaatkan kesempatan untuk menonton TV tersebut, misalnya Affandi yang menyetakan : "Kalau sekarang ini saya sudah lama tidak menonton televisi”.

Anak-anak Panti Asuhan Yatim Piatu dan Fakir Miskin Ibnu Fatah Berbah Sleman memiliki berbagai penilaian terhadap program siaran televise di Indonesia. Dianataranya adalah menurut Affandi "Iklan, sinetron dan musik dalam siaran tv kurang mendidik". Sedangkan menurut Pramono "Program siaran TV di Indonesia kebanyakan hanya mementingkan kepentingan person/seseorang tanpa memperhatikan dampak yang diakibatkan bagi penonton TV, selain itu juga jarang menyiarkan tontonan yang mendidik anak-anak dan orang dewasa. Misalnya iklan Hanya fokus dengan produk/kepemilikan dan lainnya yang anya bersifat person, sinetron banyak yang menjerumuskan ke dalam film kemaksiatan, musik yang kalau ini lumayan bagus dikarenakan dapat menghilangkan stress menenangkan pikiran, supaya lebih fresh pikirannya". Namun demikian ada juga yang menilai program siaran televise bagus, keren dan menghibur.

Media massa televisi sudah menjadi bagian dari kehidupan masyarakat. Ua hadir dalam waktu 1 X 24 jam setiap hari. Hal ini meresahkan kalangan yang sadar dampak negatifnya isi siaran tv. Anak-anak Panti Asuhan Yatim piatu dan Fakir Miskin Ibnu Fatah Berbah Sleman menilai bahwa isi siaran tv memiliki dampak positif dan negative. Dampak positifnya kita tidak ketinggalan informasi, sedangkan dampak negatifnya kita menjadi malas mengerjakan kegiatan-kegiatan yang lain.

Pengaruh isi siaran tv memang sangat kuat. Ia dapat mempengaruhi sistem nilai pada diri seseorang. Sistem nilai sendiri sering dipahami sebagai system keyakinan dalam diri seseorang yang akan dijadilan pijakan dalam berfikit, bersikap dan bertindak. Ia merukan pondasi sekaligus benteng suatu kepribadian. Ia akan membentingi dan mempertahankan dengan kokoh kepribadian-kepribadian dari hal-hal yang tidak sesuai dengan hati nurani. Namun demikian, baik disadari maupun tidak disadari system nilai tersebut dapat berubah karena factor dari luar individu seperti informasi,budaya maupun lingkungan. Menurut anak-anak Panti Asuhan Yatim piatu dan Fakir Miskin Ibnu Fatah Berbah Sleman, terpaan siaran televisi dapat merubah sistem nilai seseorang. Setiap informasi yang hadir dalam bentuk tontonan baik itu film, sinetron, iklan, reality show dan sebagainya; pasti mengandung muatan nilai tertentu. Nilai tersebut dapat menjadi sistem kebenaran baru, baik secara positif maupun ecara positif maupun negatif. Nilai-nilai yang terkandung dalam siaran tv di Indonesia dalam berbagai tayangannya banyak menghadirkan nilai-nilai yang negative. Contohnya adalah sikap konsumtif, hedonism, bersilat lidah, banyolan yang seronok, eksploitasi perempuan, adegan kekerasan dan sebagainya.

Untuk itu beberapa anak dari Panti Asuhan Yatim Piatu dan Fakir Miskin Ibnu Fatah Berbah Sleman memberikan saran untuk penonton ev sebagai berikut :

“...tontonlah acara yang layak di tonton, jangan menonton yang bisa merusak diri, jangan sampai lupa waktu dan lupa diri, ambil hikmah dan pelajaran dari yang di tonton" (Kasimin). 
"Jika menonoton TV janganlah terlalu lama dan jangan terlalu sedikit tetapi pas, serta sesuaikan dengan kebutuhan pikiran kita agar pikiran tidak terlalu penat dan malas" (Damar Pramono).

"Jangan sering-sering menonton TV" (Rizkani Fajri)

"Tontonan TV yang mengandung dampak positif daripada negative" (Buna Bahtiar)

"Kalau saran saya menonton TV nonton yang bisa untuk motivasi untuk membuka wawsan baru,/inspirasi" (Affandi).

Anak-anak Panti Asuhan Yatim Piatu dan Fakir Miskin Ibnu Fatah Berbah Sleman juga memanfaatkan internet atau media interaktif melalui HP atau warnet. Walaupun aturan dari panti melarang siswa membawa HP atau mengunjungi warnet, mereka secara sembunyisembunyi ada beberapa siswa yang memiliki HP untuk digunakan secara bersama sama (bergantian). Ada juga yang memanfaatkan warnet ketika sekolah pulangnya lebih awal dari jadwal rutin setiap harinya.

Salah seorang Pembina Panti menjelaskan bahwa aturan di Panti siswa dilarang membawa $\mathrm{HP}$ atau mengunjungi warnet. Alasannya adalah untuk menjaga konsentrasi anak dalam belajar di pendidikan formal maupun mendalami ajaran-ajaran Islam. Dikuatirkan dengan sarana komunikasi tersebut siswa akan berpacaran, mengakses situs-situs pornografi dan aspek negatif lainnya/ Siapa pun siswa yang melanggar aturan ini akan diberikan sanksi, yaitu siapa yang membawa HP akan disita atau menghancurkannya sendiri. Namun demikian selalu ada kasus siswa yang membawa HP. Biasanya mereka mendapatkannya ketika berinteraksi dengan siswa-siswa di sekolah yang berasal dari umum. Mereka bertransaksi di sekolah. Hal ini sulit dikontrol karena bersekolah di sekolah-sekolah formal yang siswa-siswanya dari berbagai macam kalangan.

Anak-anak Panti Asuhan Yatim Piatu dan Fakir Miskin Ibnu Fatah Berbah Sleman kebanyakan mereka mengakses media social, situs jual beli barang, berita dan sebagainya. Beberapa anak mengaku pernah membuka situs pornografi. Hal ini yang dikuatirkan oleh pengasuh panti karena dapat merusak psikis anak dan merusak system nilai Islami yang ditanamkan di lingkungan panti. Namun demikian mereka juga menyadari bahwa media internet mempunyai dampak positif maupun negatif seperti penutursn berikut ini :

"Dampak Positif: Mudah dan cepat saat mencari informasi, untuk komunikasi, menyalurkan hobi menulis, menambah penghasilan. Dampak Negatif: mudah terbawa informasi, kurang sosialisasi di dunia nyata, penipuan, mempengaruhi sikap dant ingkah laku, pornografi”. (Kasimin)

"Dampak positif : memudahkan pengaksesan, lebih cepat, lebih detail dan lengkap.

Dampak Negatif : terjerumus kemaksiatan, membuat malas, meniru adegan yang menyimpang" (Damar Pramono).

"Dampak positif : mengetahui banyak ilmu yang bermanfaat Negatif : jadi tambah malas" (Rizkani Fajri)

"Dampak Positif : menambah wawasan baik luar maupun dalam negeri, menabah pengetahuan (ilmu computer khususnya), membantu banyak hal, membantu cari tugas.Dampak Negatif : kecanduan bagi yang bermain game, boros uang, merusak mata, lupa waktu" (Buna Muthahar).

"Positif : mempermudah mencari data-data, tau berita yang ada sekarang, komunikasi, Negatif : membuat candu, malas" (Affandi).

Hadirnyainternet membawa dampakyang 
positif dan negative, oleh karena itu kita harus mengambil jalan bijak dalam menyikapinya. Anak-anak Panti Asuhan Yatim Piatu dan Fakir Miskin Ibnu Fatah Berbah Sleman mem Panti Asuhan Yatim Piatu dan Fakir Miskin Ibnu Fatah Berbah Slemanbe Panti Asuhan Yatim Piatu dan Fakir Miskin Ibnu Fatah Berbah Slemanrikan saran untuk pengguna internet sebagai berikut :

“Ginakan/manfaatkan dengan benar”. (Affandi)

"Sebaiknya penggunaan warnet dikalangan pelajar maupun masyarakat dipantau supaya tidak mengakses situs bisa merusak akhlaq seseorang yang manggunanakn internet." (Buna Muthahar)

"Gunakanlah internet untuk belajar bukan untuk melihat yang tidak ada gunanya" (Rizkani Fajri)

"Gunakan internet sebagai media pembelajaran dan manfaatkan untuk menambah siraman rohani serta ilmu-ilmu ang bermanfaat dalam kehidupan sehari-hari, janganlah menggunaan untuk menyimpang dari kaidah agama Islam serta perintah dan larangan Allah SWT." (Damar Pramono)

"Gunakanlah internet secara bijak dan cerdas, jangan digunakan untuk hal-hal yang negatif seperti menipu orang dan pornografi”. (Kasimin)

ModelLiterasi MediadiLingkunganPantiAsuhan Media yang paling diwaspadai adalah media massa televise dan media interaktif. Menurut Senja Yustisia, MSi salah satu cara untuk meminimalkan dampak dari isi media massa televise yang negative adalah dengan istilah "DIET TELEVISI". Asumsinya adalah otak kita juga memerlukan asupan gizi seperti fisik tubuh kita secara umum. Fisik tubuh kita agar tetap sehat membutuhkan berbagai vitamin dan mineral dari berbagai sumber makanan dan minuman yang sehat. Demikian pula otak kita juga membutuhkan informasi, pendidikan dan hiburan yang sehat (berguna) agar dapat berkreasi maupun relaksasi secara sehat pula.

Saat ini sebagian besar siaran televise yang ditonton masyarakat adalah acara-acaya yang isinya tidak sehat seperti : silet, pesbuker, tukar nasib, obsesi, dahsyat dan sebagainya. Kesadaran literacy media sangat diperlukan. Cakupannya antara lain adalah kesadaran : Pertama, setiap adegan dalam siaran televise adalah tidak sungguhan. Kedua, iklan bertujuan untuk menghasut masyarakat bertindak konsumtif. Ketiga, semua isi media cenderung berlebihan.

Dengan kesadaran literacy media tersebut diharapkan dapat meminimalkan dampak isi media. Industry televisi adalah industri yang berupaya menarik penonton yang sebanyak- banyaknya melalui seluruh program acaranya. Oleh karena acara televise cenderung berlebihan dan mengabaikan dampak negatif bagi masyarakat penonton. Semua yang dianggap mempunyai daya tarik bagi penonton akan dijadikan komoditas.

Tujuan utamanya adalah mengejar angka rating (jumlah penonton acara televise) yang akan berkorelasi pada tarif tayangan iklan setiap spot waktu iklan (30 detik). Semakin tinggi angka rating, semakin tinggi pula tariff iklan yang merupakan sumber penghasilan yang utama bagi industry media. Ketatnya persaingan antarindustri televisi dalam memperebutkan porsi iklan juga menjadi salah satu penyebab munculnya isi program siaran televisi yang bersifat rendahan dan tidak mendidik.

Sementara itu tayangan-tayangan dalam iklan juga merupakan masalah tersendiri bagi pemirsa televise. Iklan yang memang tujuannya utamanya adalah meningkatkan penjualan selalu menampilkan hiperrealitas yang sangat mengelabuhi khalayak sasarannya. Dampaknya 
sangat tidak realistis bagi khalayak untuk bertindak konsumtif. Belum lagi masalah aspek etika dalam iklan yang juga sangat meresahkan, misalnya adalah aspek pornografi dan eksploitasi terhadap aurat perempuan.

Salah satu cara atau tips untuk mengidentifikasi nilai positif atau negatif dari isi program siaran TV adalah mengenali substansinya melalui beberapa kunci nilai yang terkandung dalam siaran TV. Kata kunci nilai tersebut adalah sebagai berikut, yaitu kata kunci positif : berpikir matang, bersyukur, efisiensi, ikhlas, besar, menyeleweng kreatif, mengharga waktu, pemurah, produktif, kasih saying, sabar, sopan santun dan sebaginya. Sedangkan nilai negatifnya adalah : antisusila, iri, boros, instan, korupsi, marah, membunuh, pamer kecantikan, tidak sabar, mimpi-mimpi dan sebagainya.

Dengan mengenali nilai-nilai positif dan negative tersebut diharapkan kesadaran kita untuk menfilterisasi diri dari dampak negatif media. Diharapkan minimal muncul kesadaran kalau program siaran yang berisi isi yang negative akan dihindari, tidak akan ditiru dan member himbauan pada pihak lain untuk menghindarinya. Efek domino seperti ini diperlukan sebagai upaya untuk menyebarkan kesadaran terhadap media literacy.

Prinsip-prinsip dalam menyikapi media televisi tersebut, juga dapat dijadikan landasan dalam menyikapi media internet (media internet). Internet telah hadir dengan gelombang yang lebih dahsyat dari pada media massa apa pun. Berbagai macam informasi dari seluruh belahan dunia tersedia dalam jaringan internet, baik itu yang positif maupun negative. Keceatan dan kemudahan dalam mengaksesnya pun terus berkembang dengan pesat. Hadirnya internet akan terus menjadi eforia seiring dengan perkembangan teknologinya.

Dampak internet yang paling mencemaskan adalah "kecamduan", yaitu kondisi seseorang dimana ia terus memantau internet disetiap saat dan keadaan. Ia rela melewatkan waktu belajar, istirahat, tidur dan kegiatan apa pun demi memantau internet. Oleh karena itu ada yang menyebut, dalam perspektif Islam internet

dan sarana untuk mengaksesnya adalah alat "kebatilan" karena membuat orang lalai dengan kewajiban-kewajiban beragama. Sebuah hasil riset yang dilakukan LSM yang bergerak di bidang pemantauan penggunaan internet menyebutkan bahwa kebiasaan orang saat ini terakhir kali yang dipegang sebelum tidur adalah internet dan pertama kali yang dipegang saat bangun tidur juga internet. Hal ini sangat bertentangan dengan adab-adab dalam ajaran Islam.

Dengan melihat kondisi di atas maka deperlukan metode atau cara untuk menumbuhkembangkan anak-anak panti baik secara fisik maupun psikis di tengah-tengah terpaan media informasi yang semakin terbuka dan tanpa batas. Langkah-langkah tersebut adalah : Pertama, membuat system komunikasi yang terbuka antara pengasuh panti dan anakanak panti. Dengan komunikasi timbale balik yang terbuka tersebut diharapkan segala bentuk permasalah dan keluhan dapat dicarikan titik temmunya.

Kedua, menanamkan sistem nilai ajaran Islam yang kuat baik secara kognisi, afeksi dan konasi. Sistem nilai diharapkan akan menjadi benteng yang kuat terhadap pengaruh-pengaruh negative sistem informasi yang semakin terbuka dan tanpa batas. Idealnya adalah tumbuh self control, yaitu kesadaran diri untuk menghindari informasi-informasi yang negatif dan memilih informasi yang sehat dan positif.।

Ketiga, memperkenalkan kata-kata kunci positif dan negatif. Kata kunci nilai positif misalnya, bersyukur, efisien, kreatif, menghargai waktu, semangat, adil, bertanggungjawab, damai, taat beragama, rendah hati dan sebagainya. Kata kunci nilai negatif misalnya adalah : anti susila, boros, iri, mengumpat, adu mulut, selingkuh, ceroboh, ingkar, pamer kekayaan, mimpi-mimpi dan sebagainya. Dengan mengenali kedua nilai positif dan negatif tersebut diharapkan ikut membantu mengidentifikasi substansi isi pesan dalam media massa maupun 
media internet. Harapannya adalah dapat meminimalkan dampak negaatif terpaan media.

Keempat, menyediakan sarana akses media yang digunakan secara terbimbing dan terjadwal. Dengan demikian anak-anak panti tidak perlu mengakses media secara sembunyisembunyi. Mereka dapat menggunakan fasilitas panti di tempat yang terbuka yang dapat dilihat olej seluruh penghuni panti, terutama oleh pengasuh panti. Mereka depat memanfaatkannya untuk mencari berita, informasi dan pengetahuan yang dapat mendukung proses pembelajaran di sekolaj formal dan pendidikan agama Islam di lingkungan panti.

\section{MODEL MEDIA LITERACY DI PANTI ASUHAN YATIM PIATU DAN FAKIR MISKIN IBNU FATAH BERBAH SLEMAN}

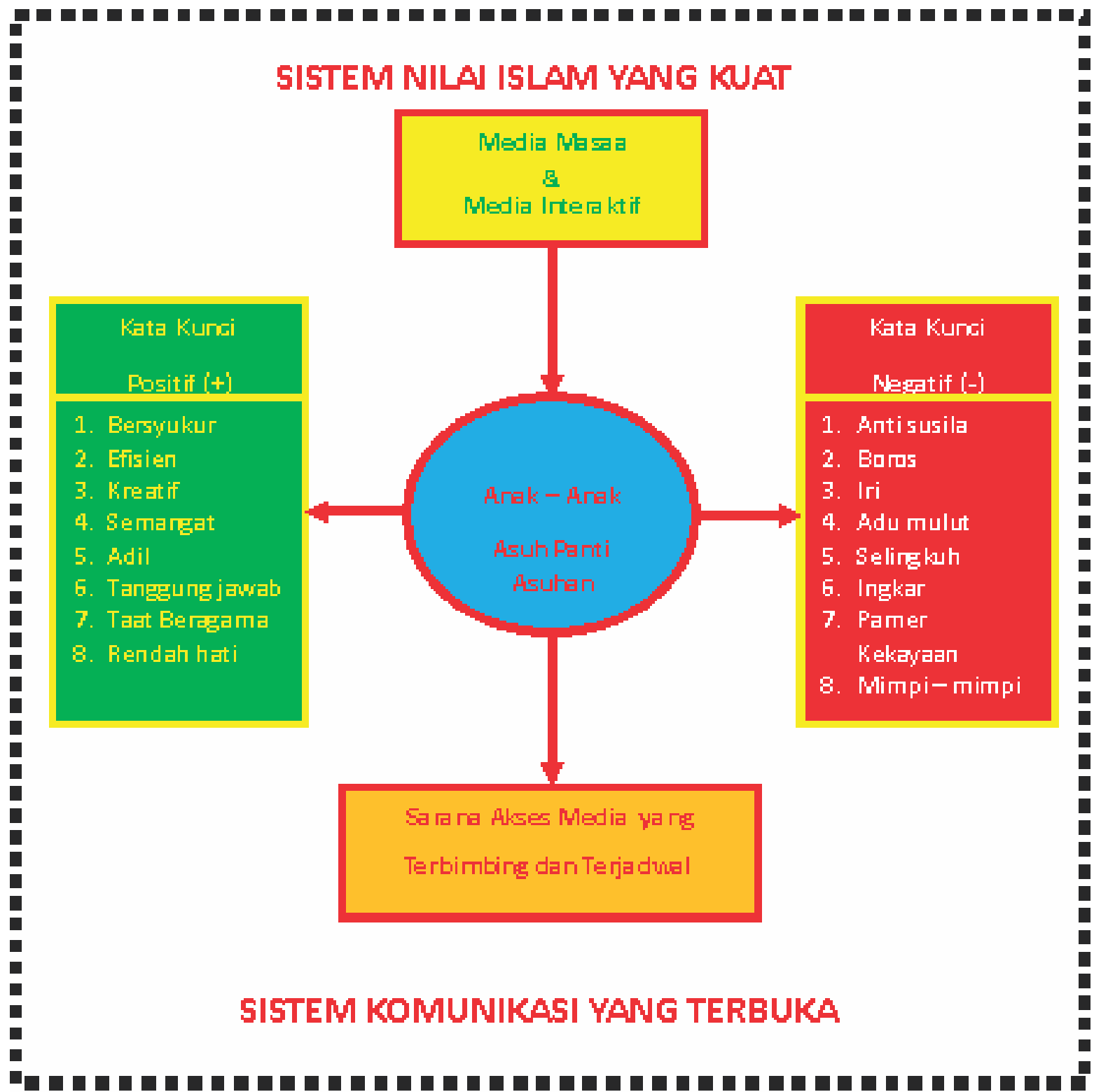




\section{Simpulan}

Penggunaan media massa dan media internet di lingkungan Panti Asuhan Yatim Piatu dan Fakir Miskin Ibnu Fatah Berbah Sleman sangat dibatasi dan dipantau, namun anak-anak panti selalu mencari kesempatan secara sembunyi-sembunyi. Mereka lebph antusias dengan media internet dari pada media ,massa. Mereka tetap mengakses situs-situs yang negative walaupun mereka juga menyadari hal tersebut negative dan merusak.

Diperlukan model media literacy dengan skema : Pertama, membuat system komunikasi yang terbuka antara pengasuh panti dan anak-anak panti. Kedua, menanamkan sistem nilai ajaran Islam yang kuat baik secara kognisi, afeksi dan konasi sebagai self control. Ketiga, memperkenalkan katakata kunci positif dan negative, Keempat, menyediakan sarana akses media yang digunakan secara terbimbing dan terjadwal.

\section{Daftar Pustaka}

Baran, Stanley and Dennis K Davis. 2000. Mass communication theory. Wadsworth: Canada

Denzin, Norman K dan Lincoln, Yvonna. 1994. Handbook of Qualitative Research.

London : $\quad$ Sage Publications Hidayat, Dedy N.,2000, Pers dalam "Revolusi Mei" Runtunya Sebuah Hegemoni, PT. Gramedia, $\begin{array}{lllllll}J & a & k & a & r & t & a\end{array}$

James, Potter W., 2005, Media Literacy, third edition. Sage Publication: New Delhi.

Littlejohn, Stephen W. 1999. Theories of Human Communication. sixth edition. California : Wadsworth Publishing Company.

McLuhan, Marshall, 2003, Understanding Media, Routledge, London and Newyork.

Neuman, W Lawrence. 2000. Social Research Methods : Qualitative and

Quantitative Approaches. fourth edition. Boston : Allyn and Bacon.

Sasangka dan darmanto. 2010, Ketika
Ibu Rumah Tangga Membaca televisi. Tifa :Yogyakarta Soemandoyo, Priyo. ND. Wacana Gender dan Layar Televisi: Studi Perempuan dalam Pemberitaan Televisi. Ford Foundation dan LP3Y: Yogyakarta. Sutopo, HB. 2002. Metode Penelitian Kualitatif. Surakarta : UNS PRESS. Wiratmojo, 2010, Ketika Ibu Rumah Tangga Membaca televisi. Tifa :Yogyakarta

\section{Internet:}

http//www.tvri.co.id 